\title{
EPIDERMAL ANATOMY OF GLYPTOSTROBUS EUROPAEUS (BRONGN.) UNGER FROM THE LATE OLIGOCENE OF THE WESTERWALD (RHINELAND- PALATINATE, W-GERMANY)
}

\author{
DIETER UHL ${ }^{1, *}$, PIA S. KRÜGER ${ }^{1}$, MICHAEL WUTTKE $^{1}$ \\ ' Senckenberg Forschungsinstitut und Naturmuseum, Senckenberganlage 25, 60325 Frankfurt am Main, Germany; \\ e-mail: dieter.uhl@senckenberg.de. \\ ${ }^{*}$ corresponding author
}

Uhl, D., Krüger, P. S., Wuttke, M. (2018): Epidermal anatomy of Glyptostrobus europaeus (BRONGN.) UNGER from the Late Oligocene of the Westerwald (Rhineland-Palatinate, W-Germany). - Fossil Imprint, 74(3-4): 334-340, Praha. ISSN 2533-4050 (print), ISSN 2533-4069 (on-line).

\begin{abstract}
Details of the epidermal anatomy of Glyptostrobus europaeus (BRONGN.) UnGER from the Late Oligocene locality Norken in the Westerwald (Rhineland-Palatinate, W-Germany) are documented and described by means of scanning electron microscopy of in situ cuticles. The taxon had a wide distribution over the entire Northern Hemisphere during the Oligocene and it is considered to represent the most common conifer during the Cenozoic of Europe, but cuticles from this taxon are rarely figured in the literature. The cuticles from Norken exhibit cellular patterns and details (e.g. of stomatal complexes) typical for taxodioid Cupressaceae. Anatomical observations are in close agreement with results for this taxon from other Central European localities. The in situ cuticles had already fragmented into very small pieces, and this explains why it was so far impossible to retrieve cuticles from this locality by means of standard cuticular analytic techniques.
\end{abstract}

Key words: Late Oligocene, Westerwald, Norken, cuticles, SEM

Received: October 25, 2018 | Accepted: November 27, 2018 | Issued: December 28, 2018

\section{Introduction}

Late Oligocene macrofloras from the Westerwald region in W-Germany have been known since at least the middle of the $19^{\text {th }}$ century (e.g. Weber 1852 , Ludwig $1859-1860$ ). Most of these floras were discovered during lignite mining but due to fast disintegration of the excavated specimens during drying, the described plants were neither abundant nor diverse. However, many studies on geology and mining the lignites and basalts of this region cited the occurrence of fossil plants at a large number of localities (e.g. Casselmann 1853, Selbach 1867, Steckhan 1973). The Oligocene macroflora from the Westerwald is thus less well known when compared to other Central European floras from this period (e.g. Central German lignite basins: Mai and Walther 1978, 1991, Mai 1995, Walther 1999, Kvaček and Walther 2001; Czech České středohoří Mts.: Walther and Kvaček 2007, Akhmetiev et al. 2009; Siebengebirge in Germany: Weber 1852, Winterscheid 2006, Winterscheid and Kvaček 2014, Winterscheid et al. 2018).

Only during recent decades have some of the macrofloras from the Westerwald gained increased scientific interest. In particular the diverse macro-flora from the Late Oligocene maar or crater lake of Enspel has been studied in some detail (e.g. Uhl and Herrmann 2010, Köhler and Uhl 2014, Uhl 2014, 2015, Uhl and Poschmann 2018). Another flora that came under the focus of current research originates from the former Lignite mine "Späth" near Norken (Müller 1997, Uhl et al. 2011, Krüger et al. 2017), located only a few kilometres north of Enspel. Whereas the Enspel flora represents a species rich mixed mesophytic forest (Köhler and Uhl 2014), the more or less contemporary macro-flora from Norken probably represents a riparian forest dominated by Acer tricuspidatum BRONN and Glyptostrobus europaeus (BRONGN.) UnGER, with only rare constituents (leaves and seeds) from other vegetation types (Müller 1997, Uhl et al. 2011, Krüger et al. 2017).

Up to now it had not been possible to extract cuticles from this flora, as the cuticles fragment into tiny, taxonomically meaningless pieces during standard preparation procedures (Krüger et al. 2017). Attempts to analyse cuticles in situ by means of Scanning Electron Microscopy (SEM) were successful for a few twig fragments, assignable to Glyptostrobus europaeus. This taxon had a wide distribution over the entire Northern Hemisphere during the Oligocene (e.g. LePage 2007) and it is considered to represent the most common conifer in the Cenozoic of Europe (Kvaček 2007), 


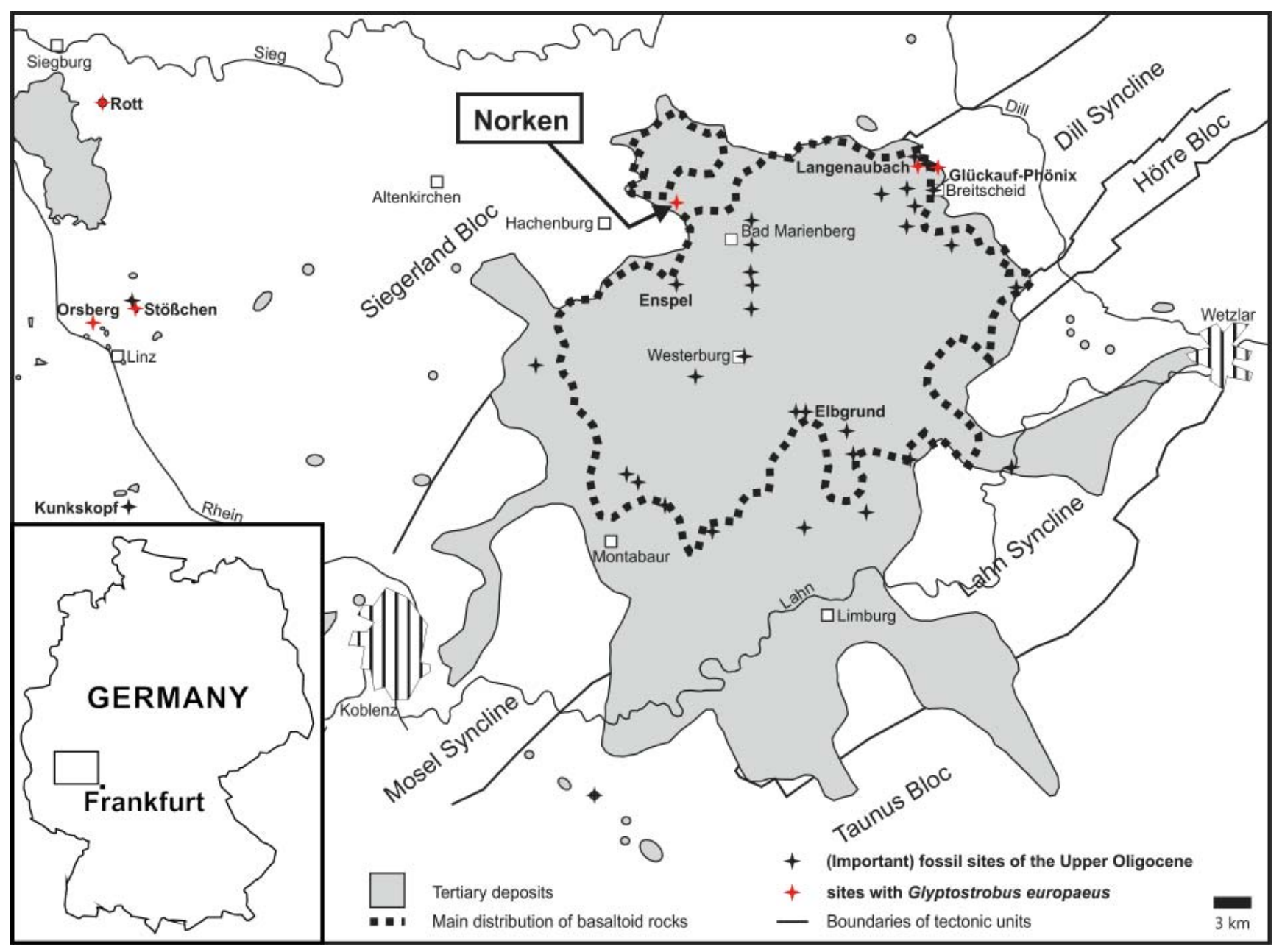

Text-fig. 1. Geological overview map of the Westerwald Tertiary; + fossil localities (after Schindler and Wuttke 2010).

but cuticles from this taxon are rarely figured in the literature (cf. Kovar-Eder 1996, Sakala 2000, Vikulin et al. 2003, Ma et al. 2013, Winterscheid and Kvaček 2014, 2016b).

\section{Geology and stratigraphy}

The village of Norken is located at the western border of the High Westerwald (Text-fig. 1). This region is part of the Rhenish Slate Mountains, which were formed during the Variscan orogeny in the late Palaeozoic. After the Variscan orogeny until the beginning of the Cenozoic, the Devonian rocks from this region experienced intensive weathering and erosion (Baumann 1993). During the Oligocene the area was subject to tectonic upheavals, resulting in the formation of numerous depressions, small basins and tectonic graben structures, which were subsequently filled with up to $100 \mathrm{~m}$ thick sediments, including claystones, black shales and lignites rich in fossils (e.g. Schäfer et al. 2011, Uhl et al. 2011). There was also an intensive volcanism in this area during the Oligocene, which led to the deposition of massive basaltic tuff/tuffite deposits, as well as basalt sheets (e.g. Schäfer et al. 2011).

The fossil bearing deposits from Norken can be assigned to the Breitscheid Formation (cf. Uhl et al. 2011) This formation is of Late Oligocene age and consists of tuffs, tuffites, siliciclastic deposits as well as lignites (e.g. Schäfer et al. 2011). The Breitscheid Formation includes three main lignite seams, of which the uppermost seam has been mined in Norken (Steckhan 1973). This seam overlies lacustrine sediments consisting of fine grained, laminated black shales, as well as coarse re-sediments probably originating from the banks of the lake (Uhl et al. 2011). For more details on the geology of the Norken locality see Steckhan (1973) as well as Uhl et al. (2011).

\section{Material and methods}

The material analysed here was collected from the spoil tips of the former lignite mine "Späth" in Norken in the Westerwald, W-Germany (Text-fig. 1). It is stored in the collections of the Maarmuseum Manderscheid (cf. Krüger et al. 2017).

Small fragments of selected pieces of the laminated black shale ("Schwarzpelit" sensu Uhl et al. 2011) exhibiting twig remains of Glyptostrobus europaeus were mounted on standard stubs with LeitC-Tabs (Plano, Münster, Germany), and subsequently examined with the aid of a JEOL JSM 6490 LV Scanning Electron Microscope (SEM; accelerator current $20 \mathrm{kV}$ ) at the Senckenberg Forschungsinstitut und Naturmuseum Frankfurt, Germany.

Measurements of anatomical details were obtained using the software ImageJ (W. S. Rasband 1997 - 2016: ImageJ. 

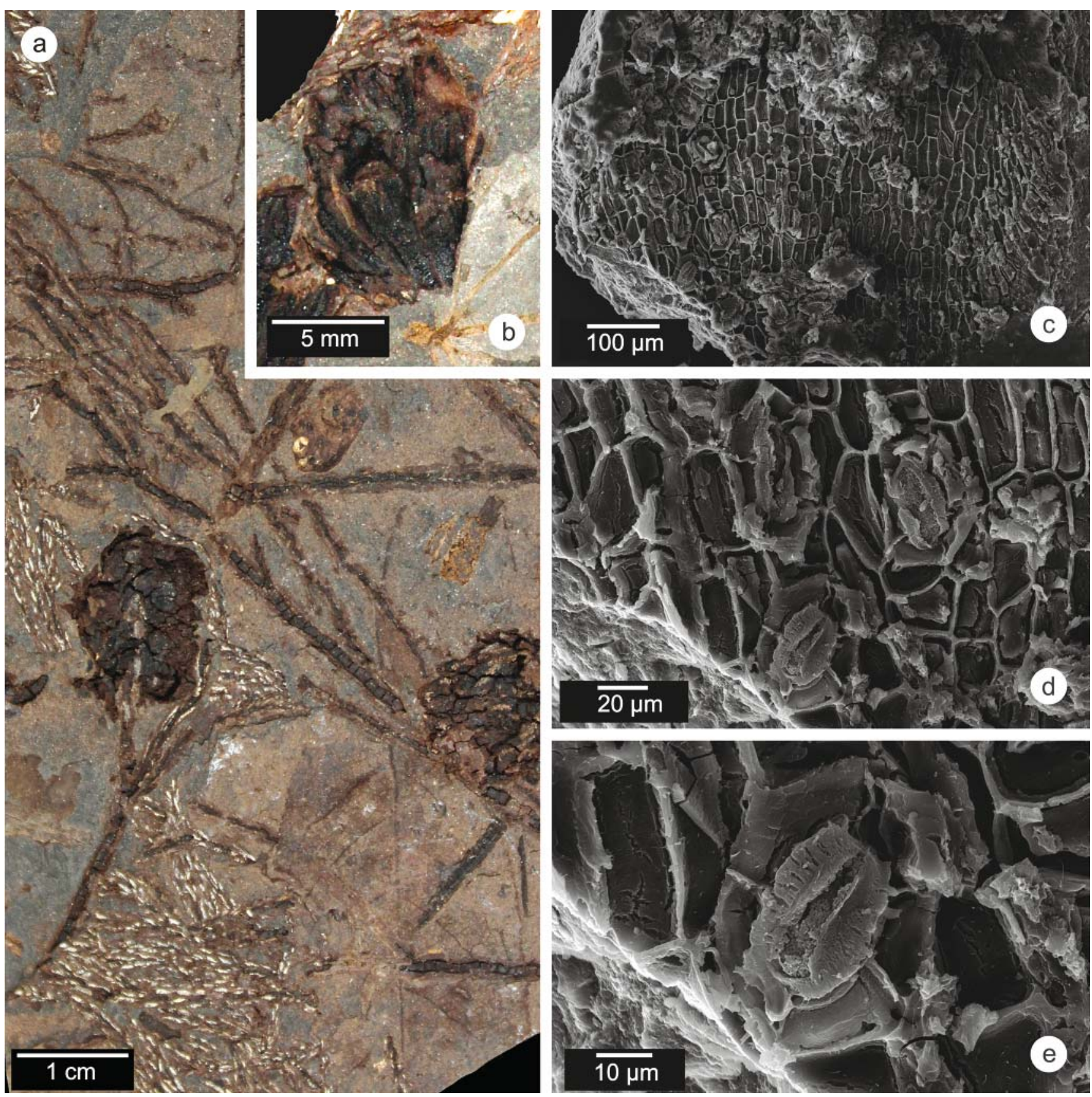

Text-fig. 2. Glyptostrobus europaeus from Norken. a) Overview of slab with twigs and two cones attached to twigs (MMM-2012-059). b) Cone exhibiting flabellate seed-scales (MMM-2012-022). c) SEM-image of the cuticle near the base of a needle (MMM-2012-059). d) Detail of c) showing stomata and fragmented cuticle. e) Detail of d) showing the cuticle around a single stomatal apparatus.

U. S. National Institutes of Health, Bethesda, Maryland, USA; http://imagej.nih.gov/ij/, last accessed: September 7th, 2018) with calibrated digital images.

\section{Systematic palaeobotany}

Family Cupressaceae Gray, nom. cons. Subfamily Taxodioideae ENDL. ex K.КосH

\section{Genus Glyptostrobus ENDL.}

The genus Glyptostrobus has been known from the Cretaceous onwards and had a wide distribution over the entire Northern Hemisphere during much of the Cenozoic (LePage 2007). Today only a single species, Glyptostrobus pensilis (StaunTON ex D.Don) K.Koch exists, occurring in Vietnam and southeast China, within the vegetation of river deltas, floodplains and lowland swamps (LePage 2007). Fossil members of this genus are also generally interpreted to represent members of swamp or riparian vegetation. However, such generalized interpretation of monotypic genera should be viewed with considerable care, as such taxa might have changed their climatic and ecological demands over time (cf. Kvaček 2007).

\section{Glyptostrobus europaeus (BRONGN.) UNGER}

Text-figs 2-3

Selected synonymy. Only references which are important for nomenclature and refer to occurrences in the 

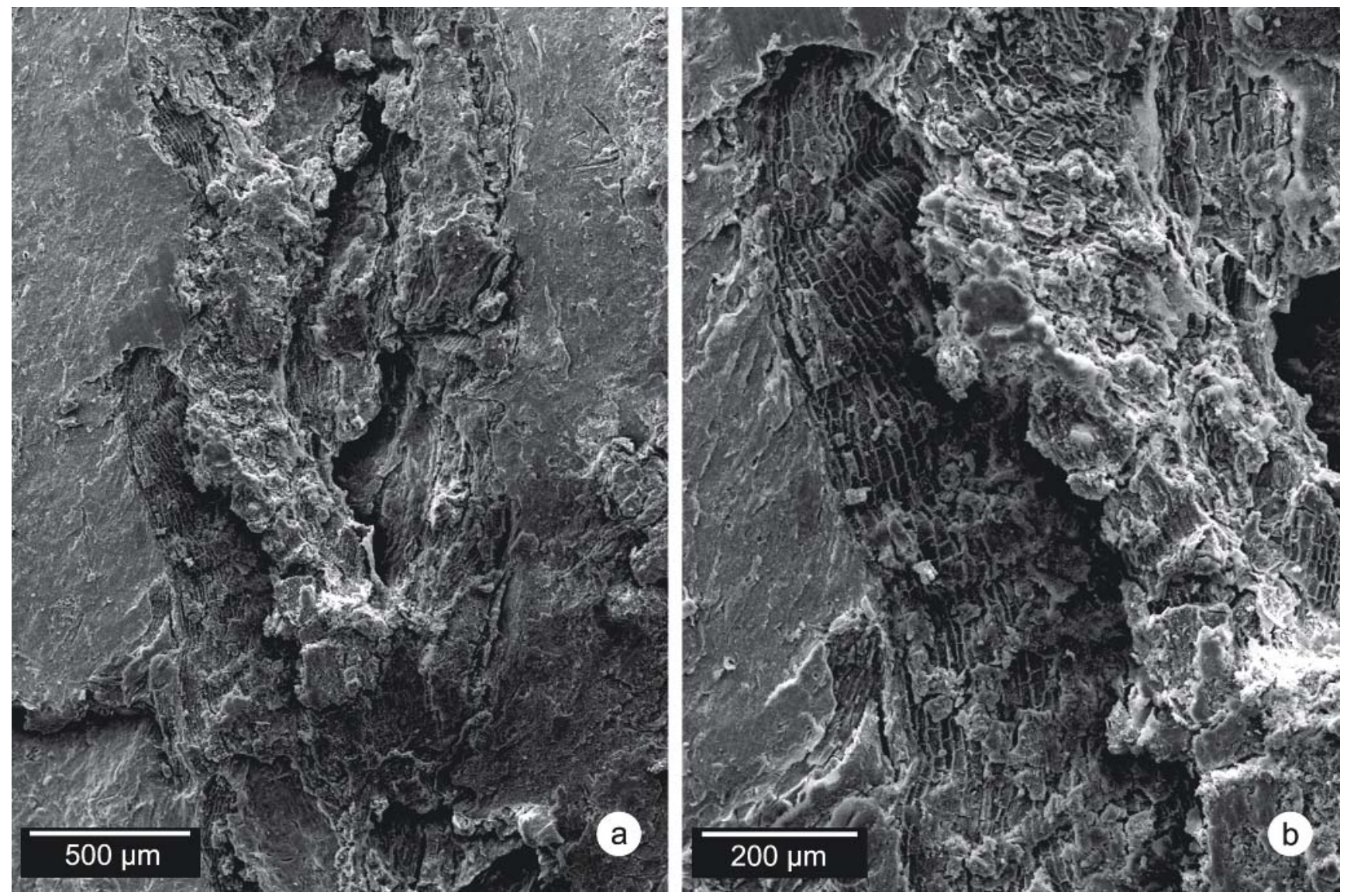

Text-fig. 3. SEM-images of Glyptostrobus europaeus from Norken. a) Detail of a split short shoot (MMM-2012-059). b) Detail of a), showing the apical part of a needle with stomatal-free zone and only a few stomata towards the base of the needle.

Westerwald or its direct vicinity; for more comprehensive lists of synonymies see LePage (2007) and Winterscheid et al. (2018).

1833 Taxodium europaeum BRONGN., pp. 168-176.

1850 Glyptostrobus europaeus (BRONGN.) UNGER, pp. 434-435.

1851 Cupressites brongniartii Göpp.; Weber, p. 161.

1937 Glyptostrobus europaeus HeER; Weyland, p. 74.

1997 Glyptostrobus sp.; Müller, p. 46.

2011 Glyptostrobus europaeus (BRONGN.) UnGER; Uhl et al., p. 121, fig. 4 .

2006 Glyptostrobus europaeus (BRONGN.) UnGER; Winterscheid, p. 74; pl. 18, fig. 1, pl. 22, fig. 8, pl. 23, fig. 9, pl. 24, figs $1-2$.

2014 Glyptostrobus europaeus (BRONGN.) UnGER; Winterscheid and Kvaček, pp. 7-8, pl. 1, figs 3-5, pl. 8, fig. 26, pl. 9, fig. 1 .

2016 b Glyptostrobus europaeus (BRONGN.) UNGER; Winterscheid and Kvaček, pp. 117-118, pl. 1, fig. 7, pl. 4, fig. 2.

2017 Glyptostrobus europaeus (BRONGN.) UNGER; Krüger et al., p. 68 , pl. $1 \mathrm{~A}-\mathrm{B}$

2018 Glyptostrobus europaeus (BRONGN.) UNGER; Winterscheid et al., pp. 124-125, pl. 4, figs 9-11.

Material. 38 twig remains of which 15 bear one or more cones at the end of the twigs (marked in bold): MMM2012-009, -018, -021, -022, -046, -049, -050, -053, -054, $-057, \mathbf{- 0 5 9}$ (SEM samples were taken from this specimen), -062, -063, -064, -065, -067, -076, -077, -080, -081, -082, $\mathbf{- 0 8 4},-085,-086,-088, \mathbf{- 0 9 0},-093,-105,-107,-110,-113$, $-116,-121,-150,-156,-189,-196,-197$.

Description. Long slender twig fragments, with cupressoid needles, up to $3 \mathrm{~mm}$ long and up to $1 \mathrm{~mm}$ wide.
15 specimens bear one or more elliptical to obovate cones at the end of the twigs (Text-fig. 2a-b). Seed-scales elongated, flabellate, thinning-out towards the base and with semicircular (abraded?) apex (Text-fig. 2b).

Only abaxial cuticles could be analysed. Normal epidermal cells in stomata free zones (Text-fig. 3a-b) are usually elongated, orientated more or less parallel to the axes of the needles, 22-72 $\mu \mathrm{m}$ (average 39.8 $\mu \mathrm{m}$ ) long and 9-24 $\mu \mathrm{m}$ (average $16.0 \mu \mathrm{m}$ ) wide. The length to width ratio of these cells is 1.3-5.2 (average 2.6). Stomatal complexes are elliptical, with (4-)5 subsidiary cells (Text-fig. 2d-e). The long-axis of the stomata are usually orientated oblique or parallel to the long axis of the needles (Text-fig. 2c). Outer walls of guard cells forming prominent lateral lamellae (Text-fig. 2d-e).

Remarks. The taxon can be identified by the characteristic form and arrangement of the needles, together with the occurrence of typical cones attached to twigs (cf. Uhl et al. 2011, Krüger et al. 2017), however the finer details of the seed-scales could not be observed in this material (cf. Text-fig. 2b). The form and arrangement of epidermal cells, as well as the stomatal complexes, clearly correspond to the published data for this taxon from other sites, as well as the only modern species G. pensilis (Tab. 1). Only small areas of the needle surfaces however could be analysed by means of SEM, due to incomplete splitting of the needles. Over all there is considerable variability in certain morphological features (e.g. size of epidermal cells), between cuticles from different fossil localities, 
ranging from Eocene up to Late Miocene, as well as in any comparison with modern G. pensilis (Tab. 1). However, as a number of cuticular features (such as cell size and orientation of stomatal complexes) varies considerably in modern $G$. pensilis, depending on needle type (linear, linear-subulate and scale-line [cuppressoid]), and even position within a needle (adaxial vs. abaxial) (Ma et al. 2004) it is difficult to interpret the variability of fossil cuticles as most come from only a few (or even single) needles. Thus it is not clear whether the observed variability in the fossil taxon may reflect ecological, climatic or even evolutionary differences between different populations of G. europaeus.

Attempts to isolate cuticles of a number of plants species from the fossiliferous sediments of Norken using standard preparation techniques have so far been unsuccessful as the cuticles fragmented into rather small and taxonomically meaningless pieces during preparation (Krüger et al. 2017). When looking at the in situ cuticles of Glyptostrobus from Norken it becomes obvious that this is due to the fact that the cuticles had already fragmented within the sediment (Text-fig. 2c-d). It is not clear whether this is due to long term diagenetic processes which affected the cuticles after deposition and before the material was mined or whether this is simply an effect of drying out and maybe oxidation after the material had been dumped on the spoil tips or even after it had been collected.

\section{Conclusions}

The occurrence of Glyptostrobus europaeus has previously been reported from a number of Late Oligocene localities in the Westerwald and adjacent areas (e.g. Müller 1997, Winterscheid 2006, Uhl et al. 2011, Winterscheid and Kvaček 2014, 2016a, b, 2018, Krüger et al. 2017). However, most of these reports were purely based on macroscopic characteristics, only Winterscheid and Kvaček (2014, 2016b) provided data on the cuticular anatomy of this taxon. The cuticular anatomy of Glyptostrobus europaeus remains from Norken clearly correspond with data from other localities, although only small areas of in situ cuticle could be analysed by SEM. Our results demonstrate that at least for the locality of Norken, SEM analysis of in situ cuticles can provide some anatomical information, adding to the purely morphological data available so far.

\section{Acknowledgements}

The authors thank Dr. Martin Koziol, Maarmuseum Manderscheid, Germany, for the loan of the study material, and Claudia Franz, Senckenberg Forschungsinstitut und Naturmuseum Frankfurt, Germany, for technical assistance with SEM facilities. We would also like to thank Z. Kvaček and S. Manchester for their constructive reviews which helped to improve the manuscript.

\section{References}

Akhmetiev, M., Walther, H., Kvaček, Z. (2009): Mid-latitude Palaeogene floras of Eurasia bound to volcanic set- 
tings and palaeoclimatic events - experience obtained from the Far East of Russia (Sikhote-Alin') and Central Europe (Bohemian Massif). - Acta Musei Nationalis Pragae Series B - Historia Naturalis, 65: 61-129.

Baumann, H. (1993): Geologie des Westerwaldes in Schwerpunkten. - In: Wegener, H.-H. (ed.), Der Westerwald. Kreis Altenkirchen und Westerwaldkreis, Stuutgart [Theiss Verlag], 26: 13-21.

Brongniart, A. (1833): Notice sur une Conifère fossile du terrain d'eau douc de Ille d'Iliodroma. - Annales des Sciences Naturelles, 30: 168-176.

Casselmann, W. (1853): Chemische Untersuchungen über die Braunkohlen des Westerwaldes. - Jahrbücher des Vereines für Naturkunde im Herzogthum Nassau, 9(2): 49-81.

Erdei, B., Magyari, E. (2011): Late Miocene plant remains from Bükkábrány, Hungary. - Studia Botanica Hungarica, 42: 135-151.

Köhler, J., Uhl, D. (2014): Die Blatt- und Karpoflora der oberoligozänen Fossillagerstätte Enspel (Westerwald, Rheinland-Pfalz, W-Deutschland). - Mainzer naturwissenschaftliches Archiv, Beihefte, 35: 1-87.

Kovar-Eder, J. (1996): Eine bemerkenswerte Blätter-Vergesellschaftung aus dem Tagebau Oberdorf bei Köflach, Steiermark (Unter-Miozän). - Mitteilungen der Abteilung für Geologie und Paläontologie des Landesmuseums Joanneum, 54: 147-171.

Krüger, P., Paudayal, K., Wuttke, M., Uhl, D. (2017): Ein Beitrag zur oberoligozänen Makroflora von Norken (Westerwald, Rheinland-Pfalz, W-Deutschland). - Mainzer naturwissenschaftliches Archiv, 54: 65-81.

Kvaček, Z. (2007): Do extant nearest relatives of thermophile European Cenozoic plant elements reliably reflect climatic signal? - Palaeogeography, Palaeoclimatology, Palaeoecology, 253: 32-40. https://doi.org/10.1016/j.palaeo.2007.03.032

Kvaček, Z., Walther, H. (2001): The Oligocene of Central Europe and the development of forest vegetation in space and time based on megafossils. - Palaeontographica, Abt. B, 259: 125-148.

LePage, B. A. (2007): The Taxonomy and Biogeographic History of Glyptostrobus Endlicher (Cupressaceae). Bulletin of the Peabody Museum of Natural History, 48: 359-426.

https://doi.org/10.3374/0079-032X(2007)48[359: TTABHO 2.0.CO;2

Ludwig, R. (1859 - 1860): Fossile Pflanzen aus der ältesten Abteilung der Rheinisch-Wetterauer Tertiärformation. Palaeontographica, 8(2-5): 39-154.

Ma, Q.-W., Li, C.-S., Li, F.-L., Vickulin, S. V. (2004): Epidermal structures and stomatal parameters of Chinese endemic Glyptostrobus pensilis (Taxodiaceae). - Botanical Journal of the Linnean Society, 146: 153-162. https://doi.org/10.1111/j.1095-8339.2004.00326.x

Ma, Q.-W., Vikulin, S. V., Li C.-S., Wang, Y.-F. (2013): Details of compressions of Glyptostrobus (Cupressaceae s.1.) from the Eocene of Fushun, NE China. - Journal of Systematics and Evolution, 51: 601-608.

https://doi.org/10.1111/jse.12035

Mai, D. H. (1995): Tertiäre Vegetationsgeschichte Europas. Gustav Fischer Verlag, Jena, Stuttgart, New York, 691 pp.
Mai, D. H., Walther, H. (1978): Die Floren der Haselbacher Serie im Weißelster-Becken (Bezirk Leipzig, DDR). Abhandlungen des Staatlichen Museums für Mineralogie und Geologie zu Dresden, 28: 1-200.

Mai, D. H., Walther, H. (1991): Die oligozänen und untermiozänen Floren NW-Sachsens und des Bitterfelder Raumes. - Abhandlungen des Staatlichen Museums für Mineralogie und Geologie zu Dresden, 38: 1-230.

Müller, P. (1997): Fossillagerstätten im Westerwald. - Westerburger Hefte, 25: 1-54.

Sakala, J. (2000): Flora and vegetation of the roof of the main lignite seam in the Bílina Mine (Most Basin, Lower Miocene). - Acta Musei Nationalis Pragae, Series B Historia Naturalis, 56: 49-84.

Schäfer, P., Schindler, T., Hottenrott, M., Wuttke, M. (2011): 5.10. Westerwald. - In: Deutsche Stratigraphische Kommission (ed.), Stratigraphie von Deutschland IX - Tertiär, Teil 1: Oberrheingraben mit angrenzenden Teilbecken und Mittelgebirgen. Schriftenreihe der Deutschen Gesellschaft für Geowissenschaften, 75: 416-435.

Schindler, T., Wuttke, M. (2010): Geology and limnology of the Enspel Formation (Chattian, Oligocene; Westerwald, Germany). - In: Wuttke, M., Uhl, D., Schindler, T. (eds), Fossil-Lagerstätte Enspel - exceptional preservation in an Upper Oligocene maar. Palaeobiodiversity and Palaeoenvironment, 90: 21-27. https://doi.org/10.1007/s12549-009-0014-4

Selbach, K. (1867): Geologische und bergmännische Beschreibung des Hohen und Oestlichen Westerwaldes. In: Odernheimer, F. (ed.), Das Berg- und Hüttenweisen im Herzogthum Nassau. Schlussheft. C. W. Kreidel's Verlag, Wiesbaden, pp. 1-108.

Steckhan, W. (1973): Die Braunkohlen des Westerwaldes. Hessisches Lagerstättenarchiv, 6: 1-114.

Uhl, D. (2014): Paläobotanische Problematika aus dem Oberoligozän von Enspel (Westerwald, Rheinland-Pfalz, W-Deutschland). - Mainzer naturwissenschaftliches Archiv, 51: 45-53.

Uhl, D. (2015): Preliminary note on fossil flowers and inflorescences from the Late Oligocene of Enspel (Westerwald, W-Germany). - Palaeobiodiversity and Palaeoenvironments, 95: 47-53. https://doi.org/10.1007/s12549-014-0172-x

Uhl, D., Herrmann, M. (2010): Palaeoclimate estimates for the Late Oligocene taphoflora of Enspel (Westerwald, W-Germany) based on palaeobotanical proxies. - In: Wuttke, M., Uhl, D., Schindler, T. (eds), Fossil-Lagerstätte Enspel - exceptional preservation in an Upper Oligocene maar. Palaeobiodiversity and Palaeoenvironment, 90: 37-46. https://doi.org/10.1007/s12549-009-0018-0

Uhl, D., Poschmann, M. (2018): Groenlandia pescheri sp. nov. (Potamogetonaceae) from the Late Oligocene Fossil-Lagerstätte Enspel (Westerwald, Germany). - Acta Palaeobotanica, 58: 61-72. https://doi.org/10.2478/acpa-2018-0001

Uhl, D., Schindler, T., Wuttke, M. (2011): Paläoökologische Untersuchungen im Oberoligozän von Norken (Westerwald, Rheinland-Pfalz, W-Deutschland) - Erste Ergebnisse. - Mainzer naturwissenschaftliches Archiv, 48: $115-127$. 
Unger, F. (1850): Sitzung vom 28. November 1850 [„,Die Gattung Glyptostrobus in der Tertiär-Formation"]. Sitzungs-Berichte der kaiserlichen Akadademie der Wissenschaften, Mathematisch-naturwissenschaftliche Classe, 5: 434-435.

Vickulin, S. V., Ma, Q.-W., Zhilin, S. G., Li, C.-S. (2003): On cuticular compressions of Glyptostrobus europaeus (Taxodiaceae) from Kaydagul Formation (Lower Miocene) of the Central Kazakhstan. - Acta Botanica Sinica, 45: 673-680.

Walther, H. (1999): Die Tertiärflora von Kleinsaubernitz bei Bautzen. - Palaeontographica, Abt. B, 249: 63-174.

Walther, H., Kvaček, Z. (2007): Early Oligocene flora of Seifhennersdorf (Saxony). - Acta Musei Nationalis Pragae, Series B - Historia Naturalis, 63: 85-174.

Weber, C. O. (1851): Ueber die Tertiärflora der niederrheinischen Braunkohlenformation. - Zeitschrift der Deutschen Geologischen Gesellschaft, 3: 391- 404.

Weber, C. O. (1852): Die Tertiärflora der Niederrheinischen Braunkohlenformation. - Palaeontographica, 2: 117 247.

Weyland, H. (1937): Beiträge zur Kenntnis der rheinischen Tertiärflora. II. Erste Ergänzungen und Berichtigungen zur Flora der Blätterkohle und des Polierschiefers von Rott im Siebengebirge. - Palaeontographica, Abt. B, 83: $67-122$
Winterscheid, H. (2006): Oligozäne und untermiozäne Floren in der Umgebung des Siebengebirges (2 volumes). - Documenta naturae, 158: 1-485.

Winterscheid, H., Kvaček, Z. (2014): Revision der Flora aus den oberoligozänen Seeablagerungen von Orsberg bei Unkel am Rhein (Rheinland-Pfalz, Deutschland). - Palaeontographica, Abt. B, 291: 1-83.

Winterscheid, H., Kvaček, Z. (2016a): Late Oligocene macrofloras from fluviatile siliciclastic facies of the Köln Formation at the south-eastern border of the Lower Rhine Embayment (North Rhine-Westphalia, Germany). - Acta Palaeobotanica, 56: 41-64. https://doi.org/10.1515/acpa-2016-0005

Winterscheid, H., Kvaček, Z. (2016b): Revision der Flora aus den oberoligozänen Seeablagerungen der Grube „Stößchen“ bei Linz am Rhein (Rheinland-Pfalz, Deutschland). - Palaeontographica, Abt. B, 294: 111-151.

Winterscheid, H., Kvaček, Z., †Váňa, J., Ignatov, M. S. (2018): Systematic-taxonomic revision of the flora from the late Oligocene Fossillagerstätte Rott near Bonn (Germany). Part 1: Introduction; Bryidae, Polypodiidae, and Pinidae. - Palaeontographica, Abt. B, 297: 103-141. https://doi.org/10.1127/palb/2018/0058 